Article

\title{
Spectral Reflectance of Palauan Reef-Building Coral with Different Symbionts in Response to Elevated Temperature
}

\author{
Brandon J. Russell ${ }^{1, *}$, Heidi M. Dierssen ${ }^{1,2}$, Todd C. LaJeunesse ${ }^{3}$, Kenneth D. Hoadley ${ }^{4}$, \\ Mark E. Warner ${ }^{4}$, Dustin W. Kemp ${ }^{5}$ and Timothy G. Bateman ${ }^{1}$ \\ 1 Department of Marine Science, University of Connecticut, Groton, CT 06340, USA; \\ heidi.dierssen@uconn.edu (H.M.D.); timothy.bateman@uconn.edu (T.G.B.) \\ 2 Department of Geography, University of Connecticut, Storrs, CT 06268, USA \\ 3 Department of Biology, Pennsylvania State University, University Park, PA 16802, USA; tcl3@psu.edu \\ 4 School of Marine Science and Policy, University of Delaware, Newark, DE 19716, USA; \\ khoadley@udel.edu (K.D.H.); mwarner@udel.edu (M.E.W.) \\ 5 Odum School of Ecology, University of Georgia, Athens, GA 30602, USA; dkemp1@uga.edu \\ * Correspondence: Brandon.Russell@uconn.edu; Tel.: +1-203-241-7253
}

Academic Editors: Stuart Phinn, Chris Roelfsema, Xiaofeng Li, Raphael M. Kudela and Prasad S. Thenkabail Received: 15 December 2015; Accepted: 13 February 2016; Published: 23 February 2016

\begin{abstract}
Spectral reflectance patterns of corals are driven largely by the pigments of photosynthetic symbionts within the host cnidarian. The warm inshore bays and cooler offshore reefs of Palau share a variety of coral species with differing endosymbiotic dinoflagellates (genus: Symbiodinium), with the thermally tolerant Symbiodinium trenchii (S. trenchii) (= type D1a or D1-4) predominating under the elevated temperature regimes inshore, and primarily Clade $C$ types in the cooler reefs offshore. Spectral reflectance of two species of stony coral, Cyphastrea serailia (C. serailia) and Pachyseris rugosa (P. rugosa), from both inshore and offshore locations shared multiple features both between sites and to similar global data from other studies. No clear reflectance features were evident which might serve as markers of thermally tolerant $S$. trenchii symbionts compared to the same species of coral with different symbionts. Reflectance from $C$. serailia colonies from inshore had a fluorescence peak at approximately $500 \mathrm{~nm}$ which was absent from offshore animals. Integrated reflectance across visible wavelengths had an inverse correlation to symbiont cell density and could be used as a relative indicator of the symbiont abundance for each type of coral. As hypothesized, coral colonies from offshore with Clade $\mathrm{C}$ symbionts showed a greater response to experimental heating, manifested as decreased symbiont density and increased reflectance or "bleaching" than their inshore counterparts with $S$. trenchii. Although no unique spectral features were found to distinguish species of symbiont, spectral differences related to the abundance of symbionts could prove useful in field and remote sensing studies.
\end{abstract}

Keywords: coral reef; reflectance spectroscopy; Symbiodinium trenchii; Cyphastrea serailia; Pachyseris rugosa; hyperspectral imaging; coral bleaching

\section{Introduction}

To a remote sensing scientist, the idea of a "coral reef" is an assemblage of different species of corals that can potentially be represented by unique spectral endmembers in a classification algorithm. Indeed, a variety of models and applications have been used to assess coral reefs from satellite and airborne multispectral imagery [1-4]. However, the concept of a "species" of coral is not quite accurate when considering spectral reflectance characteristics. Most reef-building corals are symbiotic with 
dinoflagellate symbionts (photosynthetic unicellar eukaryotes), and a calcium carbonate skeleton is overlain by host tissues containing dense populations of their endosymbionts. While coral species can contain host tissue pigments, the dominant spectral reflectance patterns for the coral arise from the pigments of symbiont populations within them [5]. Therefore, remote sensing of corals is largely remote sensing of the dinoflagellates.

The symbionts of corals are "morphologically cryptic" dinoflagellates assigned to the genus Symbiodinium [6]. Research over the past few decades has shown that the diversity of endosymbiotic dinoflagellates associated with corals is tremendous and regionally diverse [7-9]. Indeed, the symbiont assemblages associated with coral communities in the Western Pacific differ significantly from the Greater Caribbean in the Western Atlantic [10]. Moreover, coral communities from reef habitats separated by several kilometers or less may be dominated by symbiont species that are very different $[7,8,11]$. We are aware of no published research on whether communities of corals dominated by different lineages of symbiont can be distinguished based on their inherent reflectance properties. Recently, two different coral species were analyzed from the Caribbean and significant differences were found between the auxiliary pigment concentrations and the measured reflectance spectra [12], though the identities of the symbionts were not investigated.

Warming sea surface temperatures have led to frequent episodes of coral bleaching and mortality. Coral bleaching or whitening occurs when symbiotic algae are expelled from the host, however, tolerance to environmental stress varies among Symbiodinium species, and thereby colonies with thermally tolerant symbionts may avoid bleaching [13-19]. Thus changes in the resident symbiont can substantially shift the thermal tolerance of a coral colony [20]. For example, background populations of the thermally tolerant symbiont species Symbiodinium trenchii (S. trenchii) increased in the weeks leading up to and during a bleaching episode as well as subsequent to bleaching [14]. The stability of a symbiont population within a coral can be influenced by the environmental conditions under which it lives, such as temperature and irradiance. Such conditions vary with latitude, depth in the water column, and water clarity. S. trenchii is known for being a generalist inhabiting corals in marginal conditions [16], and coral colonies with this symbiont can often tolerate higher temperatures than conspecific counterparts [13,15,20-22].

When corals lose endosymbionts, their tissues become more transparent and the white and highly structured skeleton enhances colony reflectance [23-25]. Additionally, the influence of pigments from endolithic algae may then contribute to the reflectance signal [26-28]. Many studies have therefore investigated reflectance as a method of non-invasively assessing the status of both corals and symbionts. Reflectance has been used to study a variety of parameters, including discrimination between healthy, bleached, and dead coral, as well as other reef constituents like sand and macroalgae [24-26,29-31], coral diversity [5,12,32-35], disease state [36], and pigment concentration [12,37].

Hyperspectral imaging (HSI) produces a digital image with full radiance information for every pixel. In marine sciences, this technology has been primarily applied to remote sensing of large areas [38]. More recently, HSI has been applied to biological studies at small spatial scales, such as the level of a single animal or plant [39-43] and has been used to measure reflectance of individual coral fragments in the lab [44-46] and even small areas of reefs in situ [32,33]. Underwater HSI systems therefore have extreme utility in mapping, classifying and in monitoring complex benthic environments at large spatial scales that would be practically impossible for divers [47,48]. Small, portable imaging systems have been developed which can be used in the field to rapidly collect large quantities of both spectrally and spatially resolved data which cannot be practically measured with other methods like fiber optic spectroradiometry $[43,49]$.

Here, we used a portable hyperspectral imager to investigate reflectance of the mounding coral Cyphastrea serailia (C. serailia) and the laminar Pachyseris rugosa ( $P$. rugosa) from two disparate environments in Palau, Micronesia. Palau has a diverse and abundant coral system with bay, patch, barrier, and fringing reefs. These reefs are exposed to distinct temperature and water quality regimes [50,51]. We explored whether coral-dinoflagellate mutualisms from warm turbid bays or 
cooler clear-water offshore reefs harbor distinct lineages of algal symbionts, and whether these associations possess unique reflectance features which may be useful from a remote sensing perspective. As part of a larger study, we also examined if inshore corals possessed greater tolerance to elevated temperatures (i.e., avoid bleaching) than the same species from offshore reefs through the use of reflectance measurements.

\section{Materials and Methods}

\subsection{Study Sites}

The Republic of Palau is a $700 \mathrm{~km}$ long archipelago in the western Pacific (Figure 1A), that has a great variety of coral taxa and symbionts [15,50,52]. Several thermally induced bleaching events have occurred in recent years (1998 and 2010), and the subsequent recovery surveyed [50,51]. Temperatures in the bays of the Rock Islands are significantly higher than those at patch or outer reefs, and yet bleaching during the 2010 thermal anomaly was highest for patch and outer fore reef corals [49].
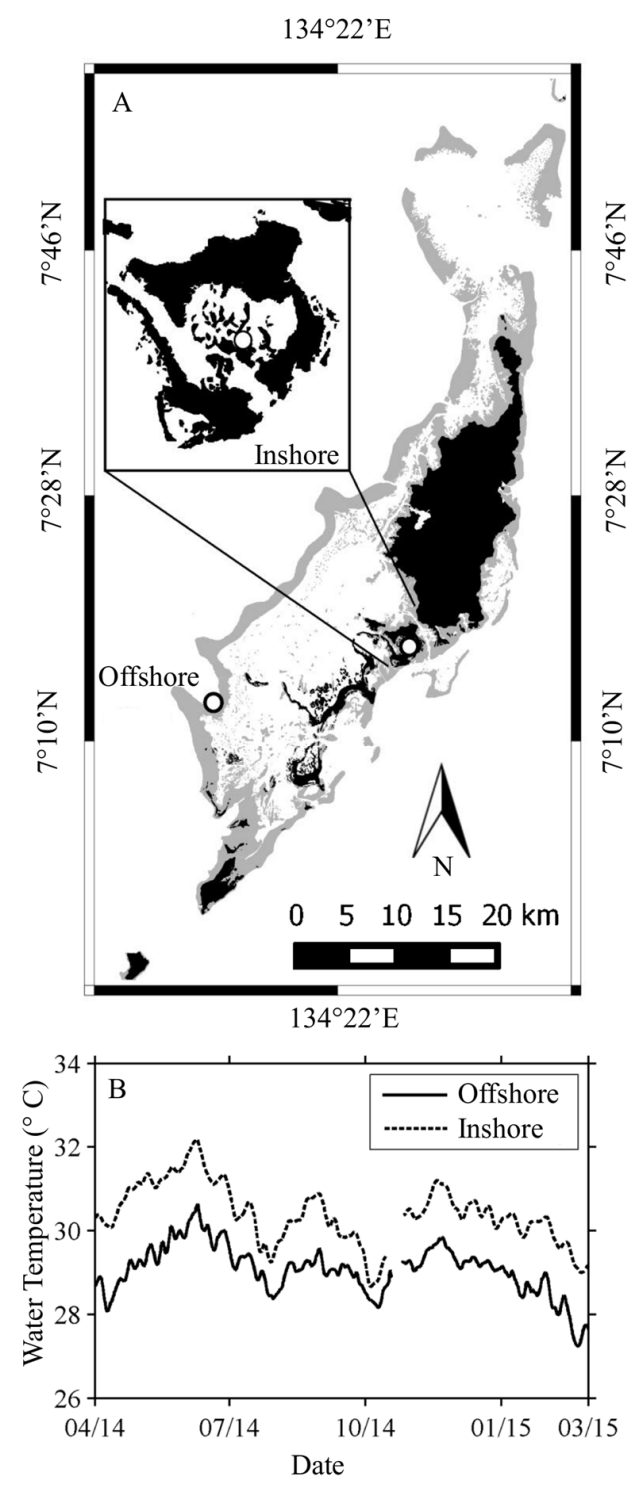

Figure 1. Study location. Palau is a Micronesian archipelago (A) with a variety of coral environments including bay, patch, barrier, and fringing reefs. The Inshore site at Nikko Bay is a shallow, warm bay near the city of Koror. The Offshore site is a barrier reef with more oceanic type water and consistently cooler temperatures $(\mathbf{B})$ than the Inshore site. 


\subsubsection{Nikko Bay-Inshore}

Nikko Bay is a shallow, warm embayment within the Rock Islands and located in close proximity to the city of Koror (Figure 1A). Light attenuation at this site is significantly higher than for offshore reefs [50]. The temperature regime in Nikko Bay is approximately $0.5-2{ }^{\circ} \mathrm{C}$ higher (Figure 1B) than at the Offshore site, Rebotel Reef [51]. Preliminary research indicated that many coral taxa at this site (hereafter referred to as "Inshore") are host to S. trenchii.

\subsubsection{Rebotel Reef-Offshore}

This location (hereafter referred to as "Offshore") is a shallow to moderate depth site on Rebotel Reef, with relatively minimal influence from human activities (Figure 1A). The water is clear and oceanic with high light transmission [50], cooler temperatures, higher $\mathrm{pH}$ [53] and lower dissolved inorganic carbon [53] than Nikko Bay (Table 1). Initial genetic assays at this location showed a variety of Symbiodinium spp. associated with coral taxa, however, very few instances of symbioses with S. trenchii have been found from this habitat.

Table 1. Water quality of study locations.

\begin{tabular}{ccccc}
\hline \multicolumn{5}{c}{ Parameter } \\
\hline Site & Temp $\left({ }^{\circ} \mathbf{C}\right)$ & $\mathbf{p H}$ (Total) [53] & DIC $\left(\mu \mathbf{m o l} \cdot \mathbf{k g}^{-1}\right)[53]$ & $\boldsymbol{K}_{\text {PAR }}\left(\mathbf{m}^{-1}\right)$ [50] \\
\hline Inshore-Nikko Bay & $30.3 \pm 0.8$ & $7.84 \pm 0.00$ & $1782.7 \pm 4.1$ & 0.129 \\
Offshore-Barrier Reefs & $29.0 \pm 0.7$ & $8.05 \pm 0.01$ & $1835.3 \pm 15.6$ & 0.085 \\
\hline
\end{tabular}

The inshore Nikko Bay reef experiences higher temperatures (yearly mean), lower $\mathrm{pH}$ [53], lower Dissolved Inorganic Carbon (DIC) [53], and greater diffuse light attenuation $\left(K_{P A R}\right)$ [50] than offshore barrier reefs. Data for offshore reefs is from multiple locations in Palau. Temperatures were collected during this study at Nikko Bay and Rebotel Reef.

\subsection{Coral Collection and Maintenance}

Eight independent colonies of $C$. serailia and P. rugosa were sampled by divers at depths between 5 and $10 \mathrm{~m}$ Inshore and 5-15 m Offshore. Samples were returned to the lab in shaded containers. Experiments were conducted at the Palau International Coral Reef Center (PICRC). Colonies were maintained in a thermally regulated, natural seawater flow-through system $\left(27.5^{\circ} \mathrm{C}\right)$ during processing. Colonies were cut into approximately $3 \mathrm{~cm} \times 3 \mathrm{~cm}$ fragments using a tile saw, transferred to shaded experimental tanks, and allowed to acclimate for $>48 \mathrm{~h}$ before mounting to plastic tiles using Z-Spar 2 part marine epoxy. After mounting, fragments acclimated to ambient treatment conditions for an additional 10 days.

\subsection{Experimental Setup}

Each treatment system consisted of between 7 and $12(56 \mathrm{~L})$ plastic treatment bins connected to a central ( $1200 \mathrm{~L}$ ) sump. Each sump was continuously supplied with seawater collected directly off of the PICRC pier at a depth of $3 \mathrm{~m}$. Seawater passed through a pressurized sand-bed and aquarium filter pads prior to reaching the sump. Seawater was heated to desired temperatures within the sump via titanium heating elements and then pumped to treatment bins. Treatment bins were setup outdoors, underneath a $60 \%$ shade cloth allowing for a peak midday light intensity of $800 \mu \mathrm{mol}$ quanta $\mathrm{m}^{-2} \cdot \mathrm{s}^{-1}$. Treatment bins were regularly scrubbed to prevent algal fouling throughout the experiment. For each treatment, three replicate fragments from each colony were placed within separate treatment bins. Within the high temperature treatment, temperature was gradually ramped from $27.5^{\circ} \mathrm{C}$ to $32{ }^{\circ} \mathrm{C}$ over $96 \mathrm{~h}$, and then maintained at $32{ }^{\circ} \mathrm{C}$ for an additional 10 days (14 days total). Temperature within the ambient temperature treatment was maintained at $27.5^{\circ} \mathrm{C}$ throughout the full 14 day experiment. 
Symbiotic algae density and genotype was assessed initially (Day 0), and then again after 9 and 14 days under experimental conditions.

\subsection{Symbiont Species and Density}

To determine the density of symbionts in host tissue, fragments representative of each coral colony from treatment and control tanks were sacrificed at Days 0, 9, and 14. Tissue was removed from fragments using a pressurized blast of air and seawater [54]. The resulting cell slurry was centrifuged at $1000 \mathrm{~g}$, the supernatant discarded, and the resulting pellet of symbiont cells preserved with $10 \mu \mathrm{L}$ of $1 \%$ glutaraldehyde for cell enumeration [55] and DNA extractions [10]. Symbionts were identified through amplification of the internal transcribed spacer 2 region (ITS2) of the ribosomal array, and analyzed by previously published protocols for denaturing gradient gel electrophoresis (DGGE) and sanger sequencing [7], relying on the ribosomal internal transcribed spacer sequences as proxies for species resolution. Cell density was recorded by light and fluorescence microscopy. Four independent replicate counts were performed for each algal sample on a hemocytometer. Samples were photographed using an EVOS digital microscope $(4 \times$ magnification) and analyzed using the software Image J (NIH) with the Analyze Particles function using methods similar to Suggett et al. [56]. Surface area was determined via the foil method [57].

\subsection{Imaging and Reflectance Processing}

Spectral reflectance, the ratio of light backscattered from a target to that incident on it at every wavelength, of a coral sample results from the interaction of animal and endosymbiont pigments. A subset of fragments was selected for reflectance measurements. Spectral data was collected with a 710 VP (Surface Optics Corp, San Diego, CA, USA) hyperspectral imager. The imager collects a data cube, a $520 \times 696$ pixel image with full spectral radiance information at $5 \mathrm{~nm}$ increments between 380 and $1040 \mathrm{~nm}$. Final spatial resolution was on the order of 10,000 pixels per $\mathrm{cm}^{2}$. The imager was mounted on a tripod at an approximately normal viewing angle (i.e., with the sensor looking vertically downward) with data collected under solar illumination between 10:00 a.m. and 2:00 p.m. local time.

During imaging, coral fragments were submerged (approximately $10 \mathrm{~cm}$ depth) in a tank lined with black cloth. To minimize stress and thermal effects on corals, fragments were gently and rapidly transferred from flow-through experimental tanks to the imaging tank, scanned (typically $30 \mathrm{~s}$ ), and returned to the experimental system. Water in the imaging tank was taken from the treatment for that fragment group (heated or control). Water was changed frequently to avoid excessive heating. A Spectralon (LabSphere) 10\% reflectance standard was included in every data cube for calculation of reflectance $R(\lambda)$ at the same depth as the coral sample. A $10 \%$ standard was selected to maximize the signal-to-noise ratio for reflectance of relatively dark coral samples [30]. Bubbles were removed from the standard by gentle polishing with 400-grit wet/dry sandpaper while submerged. Coral fragments were mounted horizontally, providing a near laminar surface.

ENVI (Exelis VIS) image analysis software was used for the processing of data cubes (Figure 2). Regions of Interest (ROIs) were generated manually with visual inspection so as to avoid glare contaminated and saturated pixels. Cubes with heavy glare or contamination from surface reflectance were discarded from analysis. ROIs were created for 3 elements in all remaining images: a Spectralon standard, the black background, and the coral. For coral ROIs, pixels near to the edge of the marine epoxy were avoided. From these ROIs, mean spectra (as dimensionless numbers) were extracted for processing. These signals were corrected for sensor noise using a dark signal collected during imaging. Due to signal to noise limitations of the imager, the spectral region considered is limited to $400-700 \mathrm{~nm}$, interpolated to $1 \mathrm{~nm}$ using Piecewise Cubic Hermite Interpolating Polynomial (PCHIP).

As the reflectance of the standard under water diverged from the calibrated value [58], we therefore measured its reflectance relative to a $99 \%$ Spectralon standard (with bubbles removed from both standards) independently from data collection. This value, $R_{s t d}(\lambda)$, was then used in 
calculating coral reflectance (Table 2). All parameters in calculating reflectance are fully spectral, with $(\lambda)$ dropped for clarity.
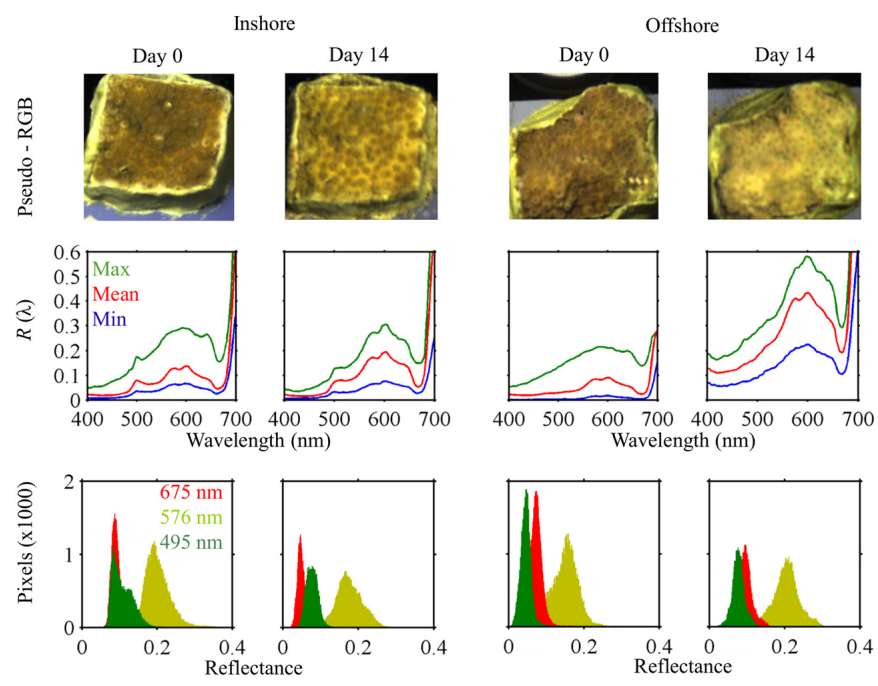

Figure 2. Hyperspectral imaging of Cyphastrea serailia at Day 0 and 14. Pseudo-RGB images (top row) illustrate the different degrees of pigment loss evident between Inshore and Offshore colonies after heating. Mean fragment reflectance (middle row) shows an increase in $R(\lambda)$ for the Inshore fragment, and a pronounced increase for Offshore. The shift in pixel histograms for reflectance at select wavelengths (bottom row) with bleaching are evident from the hyperspectral imagery, and HSI is far more efficient at revealing the distribution of variability of reflectance than techniques like fiber-optic spectroradiometry.

Table 2. Summary of symbols, definitions, and units.

\begin{tabular}{ccc}
\hline Symbol & Definition & Unit \\
\hline$L_{c r l}$ & $\begin{array}{c}\text { Radiance of coral pixels } \\
\text { Radiance from surface } \\
L_{g l r}\end{array}$ & $\mathrm{~W} \cdot \mathrm{m}^{-1} \cdot \mathrm{sr}^{-1}$ \\
$L_{s t d}$ & Radiance of Spectrance & $\mathrm{W} \cdot \mathrm{m}^{-1} \cdot \mathrm{sr}^{-1}$ \\
$R_{s t d}$ & Reflectance of Spectralon & $\mathrm{W} \cdot \mathrm{m}^{-1} \cdot \mathrm{sr}^{-1}$ \\
$R_{b l k}$ & Reflectance of black background & Dimensionless number \\
$R_{c r l}$ & Reflectance of coral & Dimensionless number \\
& & Dimensionless number \\
\hline
\end{tabular}

Coral fragments were submerged in seawater, while the imager was in air above the imaging tank. As such, contamination of radiance spectra by surface reflection represents a potentially non-trivial source of error, hereafter referred to as glare. This signal must be removed from coral and reflectance standard radiance spectra before calculating coral reflectance. Consistent with ocean color remote sensing, we consider the radiance from glare to be an additive component to the total radiance measured at the sensor. Glare radiance $L_{g l r}$ was set equal to the raw radiance $L_{b l k}$ of black background pixels over the spectral region where $R_{b l k}$ is near zero $(400-638 \mathrm{~nm})$. This signal also includes any photons that were reflected from within the water column itself. At longer wavelengths $(639-700 \mathrm{~nm})$, $L_{g l r}(\lambda)=L_{b l k}(638 \mathrm{~nm})$ because there was some non-negligible reflectance from the black cloth at far red wavelengths. Finally, coral radiance spectra extracted from the imagery were converted to Lambertian equivalent reflectance as:

$$
R_{c r l}=\left[\left(L_{c r l}-L_{g l r}\right) \times R_{s t d}\right] /\left(L_{s t d}-L_{g l r}\right)
$$

where $L_{c r l}$ is the raw signal of coral pixels. To remove noise due to environmental factors including capillary waves due to non-flat water surface and low signal in some wavelengths, spectra were smoothed 3 times with a Savitsky-Golay filter of order 3 and $15 \mathrm{~nm}$ width $[5,12,25,26]$. Standard deviation of $R_{c r l}$ was also generated for each fragment from the imagery. 


\subsection{Reflectance and Symbiont Density Comparison}

An exponential regression was fit to symbiont density and integrated reflectance for fragments on Day 0. Reflectance spectra were integrated as:

$$
\sum R=\int_{400}^{700} R_{c r l}(\lambda) d \lambda
$$

Colonies of both species were grouped by reef/symbiont type for analysis.

\subsection{Reflectance Analysis}

Differences in reflectance between species, sites, and temperature treatment were tested for significance at each wavelength (Mann-Whitney U test) for significance, utilizing mean reflectance for each fragment.

The location of peaks in the 2nd derivative of reflectance has been linked to the absorption spectra of specific endosymbiont and host pigments and can be utilized to locate important reflectance features $[12,24-26,30,36]$. The 2 nd derivative of reflectance $\left(\frac{d^{2} R}{d \lambda^{2}}\right)$ was calculated for each fragment at Day 0 and peaks located during processing.

\section{Results}

\subsection{Symbiont Species and Density}

Symbionts in Inshore colonies for both $C$. serailia and $P$. rugosa were identified as Symbiodinium trenchii [15]. Offshore, seven C. serailia colonies harbored Symbiodinium type C3u and one colony contained C40 (ITS2 type designations). Of the eight Offshore P. rugosa colonies, five contained Symbiodinium C40 symbionts, one hosted Cunk (Clade C unknown), and two were associated with S. trenchii. As the purpose of this study was to examine spectral reflectance with regard to symbiont type, those Offshore P. rugosa colonies containing S. trenchii were excluded from analysis of Offshore P. rugosa and instead included in the "Inshore" group containing S. trenchii.

Median symbiont densities, on the order of $10^{6}$ cells per $\mathrm{cm}^{2}$ of coral surface area, were similar (Figure 3) for C. serailia colonies from both Inshore (labeled "NCs") and Offshore (labeled "OCs"), as well as Inshore P. rugosa colonies (labeled "NPr"). Corals from Inshore reefs, containing S. trenchii, had (non-significantly) higher densities than their Offshore counterparts (with multiple $C$ type symbionts) for both coral species. Offshore P. rugosa (labeled "OPr") colonies had lower densities than Inshore corals (Mann-Whitney U test, NCs: $p=0.03$, NPr: $p=0.05$ ) and Offshore C. serailia $(p=0.1)$.

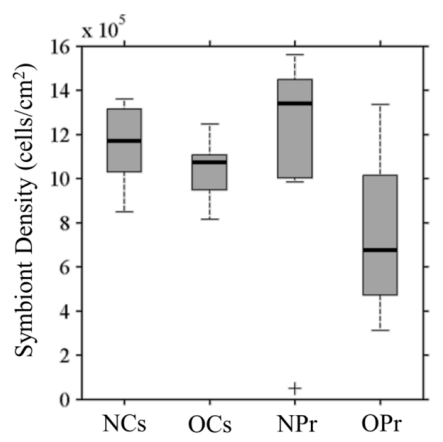

Figure 3. Initial symbiont cell density in coral colonies. Density of symbiont cells per $\mathrm{cm}^{2}$ of coral fragments are given for Inshore $(\mathrm{N})$ and Offshore $(\mathrm{O})$ colonies of Cyphastrea serailia $(\mathrm{Cs})$ and and Pachyseris rugosa $(\mathrm{Pr})$. Horizontal bars are colony median density (on the order of $10^{6}$ cells $/ \mathrm{cm}^{2}$ ), crosses represent outliers. 


\subsection{Spectral Reflectance}

\subsubsection{Cyphastrea serailia}

The reflectance of Inshore and Offshore C. serailia share several spectral features (Figure 4, top). In particular, peaks at 580 and $605 \mathrm{~nm}$, and a shoulder at $655 \mathrm{~nm}$ were observed for colonies from both locations. These are similar to features in other published coral spectra $[5,30,35]$. However, Inshore colonies show a distinct reflectance peak, likely due to fluorescence, at 490-505 nm that was not observed for Offshore colonies. Inshore and Offshore colonies were similarly reflective in the blue (400-490 nm), while Inshore $R(\lambda)$ was significantly (Mann-Whitney $U$ test, $p<0.05$ ) higher than Offshore between 492 and $547 \mathrm{~nm}$. Additionally, mean reflectance of $C$. serailia from Inshore showed a higher standard deviation than Offshore at most wavelengths.

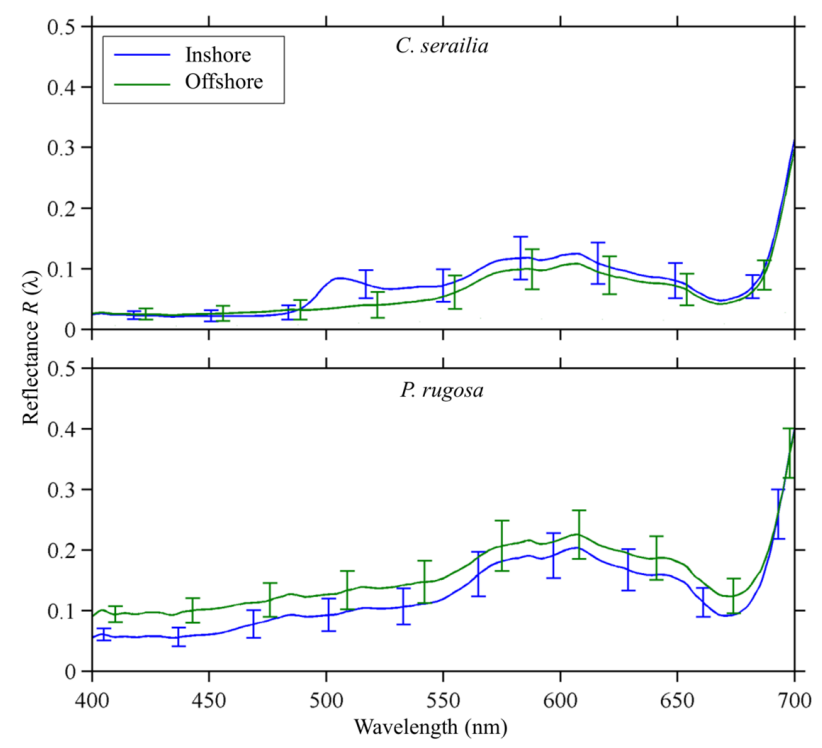

Figure 4. Mean reflectance of colonies from Inshore (S. trenchii) and Offshore (Clade C) reefs for Cyphastrea serailia (top) and Pachyseris rugosa (bottom). Spectral shapes from both locations are similar for both species, with the exception of green fluorescence at approximately 490-500 nm present in the Inshore $C$. serailia. Error bars represent \pm 1 standard deviation, as the square root of the pooled variances for each fragment in the species/site group. Eight fragments were averaged for each curve, except Offshore P. rugosa where two fragments with S. trenchii were omitted.

\subsubsection{Pachyseris rugosa}

The reflectance of Inshore and Offshore P. rugosa were very similar in spectral shape (Figure 4, bottom), though Offshore colonies were significantly $(p<0.05)$ more reflective than Nikko Bay in lower (400-471 nm) wavelengths. As with C. serailia, standard deviation was generally higher for Nikko Bay colonies. The features seen in C. serailia at 580, 605, and $655 \mathrm{~nm}$ were also observed in P. rugosa, with the addition of two slight peaks at 480 and $512 \mathrm{~nm}$. A very slight peak was observed in all treatments at $405 \mathrm{~nm}$.

\subsubsection{Derivative Analysis}

The major spectral features were found to be common to colonies of both species and locations (Figure 5). Second derivative peaks at 412, 420, 434, 455, 492, 524, 550, 559, 579, 593, 617, and $636 \mathrm{~nm}$ were found $( \pm 1 \mathrm{~nm})$ in the mean second derivative spectra of all groups (Table 3). Additional peaks at 474 and $505 \mathrm{~nm}$ were present in all colonies except Inshore $C$. serailia. A peak at $536 \mathrm{~nm}$ was present in Offshore C. serailia and Inshore P. rugosa, at $668 \mathrm{~nm}$ in all colonies except Offshore P. rugosa, and at $689 \mathrm{~nm}$ in all but Inshore P. rugosa. The locations of all peaks were not different when using normalized 
or non-normalized spectra. For P. rugosa, the magnitude of Offshore peaks was greater in the lower (400-500 nm) wavelengths.

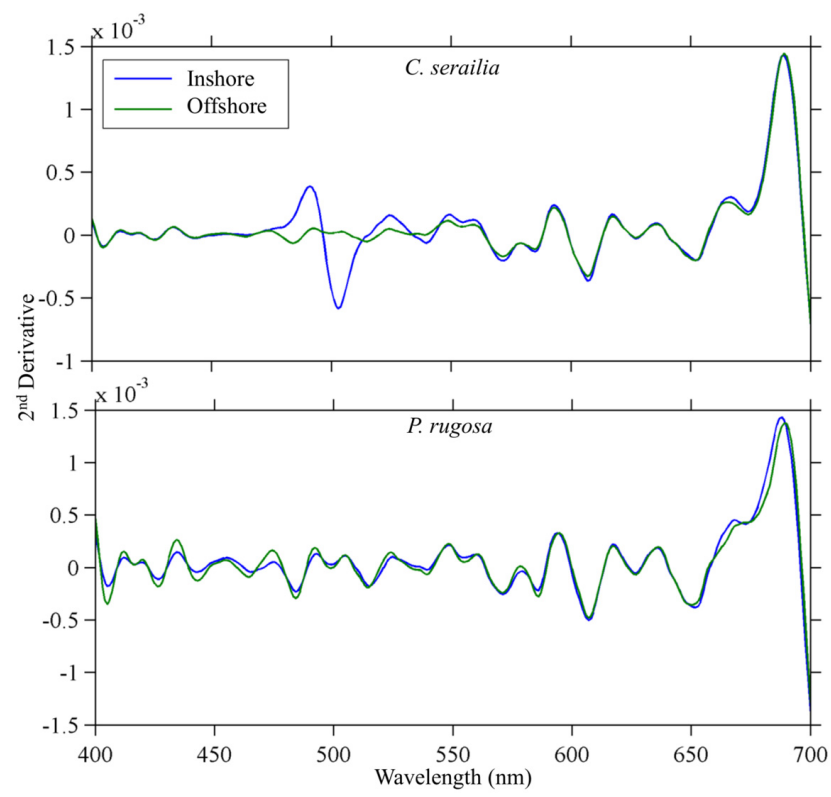

Figure 5. Mean second derivative of $R(\lambda)$ for both species. For Cyphastrea serailia (top), second derivative peak location and magnitude are almost identical except from $475-550 \mathrm{~nm}$, due to the presence of a large $R(\lambda)$ feature in Inshore colonies. Pachyseris rugosa (bottom) colonies showed peaks at identical locations between sites. Error bars have been omitted for clarity.

Table 3. Second derivative peak wavelengths in mean reflectance spectra for coral species and site/symbiont combinations. Presence of a peak at given wavelength is indicated by + , absence by -.

\begin{tabular}{ccccc}
\hline & \multicolumn{2}{c}{ C. serailia } & \multicolumn{2}{c}{ P. rugosa } \\
\hline Wavelength $(\mathbf{n m})$ & Inshore & Offshore & Inshore & Offshore \\
\hline & S. trenchii & C Type & S. trenchii & C Type \\
\hline 412 & + & + & + & + \\
420 & + & + & + & + \\
434 & + & + & + & + \\
455 & + & + & + & + \\
474 & - & + & + & + \\
492 & + & + & + & + \\
504 & - & + & + & + \\
524 & + & + & + & + \\
536 & - & + & + & - \\
549 & + & + & + & + \\
559 & + & + & + & + \\
579 & + & + & + & + \\
593 & + & + & + & + \\
617 & + & + & + & + \\
636 & + & + & + & + \\
666 & + & + & + & - \\
689 & + & + & - & + \\
\hline
\end{tabular}

\subsubsection{Inshore vs. Offshore}

Reflectance spectra of Inshore (S. trenchii) and Offshore (Clade C) colonies were grouped for inter-site comparison. No wavelengths were found to be significantly different (Mann-Whitney U test, $\alpha=0.05$ ) between sites. This result remained true when spectra were normalized to their maximum value in the region considered due to significant differences in overall magnitude of reflectance and 
initial symbiont cell density between some species/site combinations. There were no unique second derivative features common across both Inshore corals when compared to both Offshore corals.

\subsection{Reflectance and Symbiont Density Comparison}

Inverse exponential relationships between symbiont density $\left(\mathrm{cells} / \mathrm{cm}^{2}\right)$ and integrated reflectance $\Sigma R$ were observed for both coral species and dinoflagellate type (S. trenchii vs. Clade C). Exponential regressions between $\Sigma R$ and the density differed for host/dinoflagellate combinations (Figure 6). Predictability ranged between $47 \%$ and $75 \%$, with distinct relationships depending on coral/symbiont.

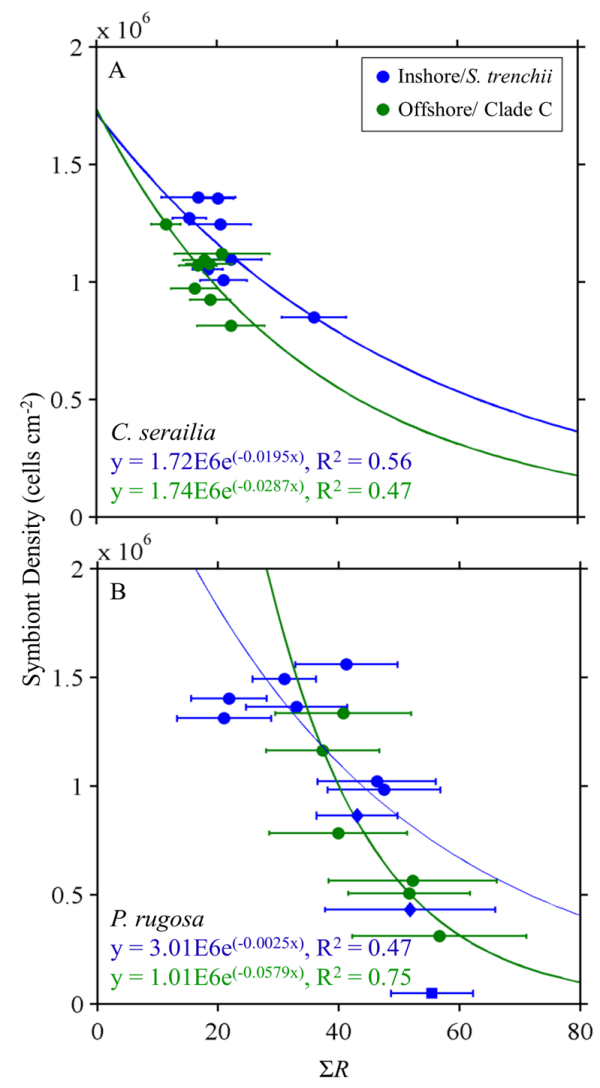

Figure 6. Integrated reflectance and symbiont density for colonies of Cyphastrea serailia (A) and Pachyseris rugosa (B). For each coral, both kinds of symbiont showed an inverse relationship for each coral with a range of predictability. Error bars are \pm 1 standard deviation of $\Sigma R$. Blue diamonds are P. rugosa from Offshore that contained Symbiodinium trenchii, and so were included with Inshore P. rugosa for analysis. Blue square represents a sample of Inshore P. rugosa whose symbiont density was considered to be an outlier and was excluded from regression.

\subsection{Response to Heating}

\subsubsection{Symbiont Density}

Cyphastrea serailia control fragments from Inshore (Figure 7A) had lower (Mann-Whitney U test, $p=0.05$ ) cell density (S. trenchii) on Day 14 than Day 0, but control and heated densities were not different $(p=0.16)$. A slight increase in median density was observed for heated fragments between Days 9 and 14. Offshore C. serailia (Figure 6B) cell density (Clade C types) decreased significantly for both control and heated fragments by Day $14(p<0.001)$, but the heated fragments had approximately $50 \%$ less algal cells than the control fragments $(p=0.001)$. 

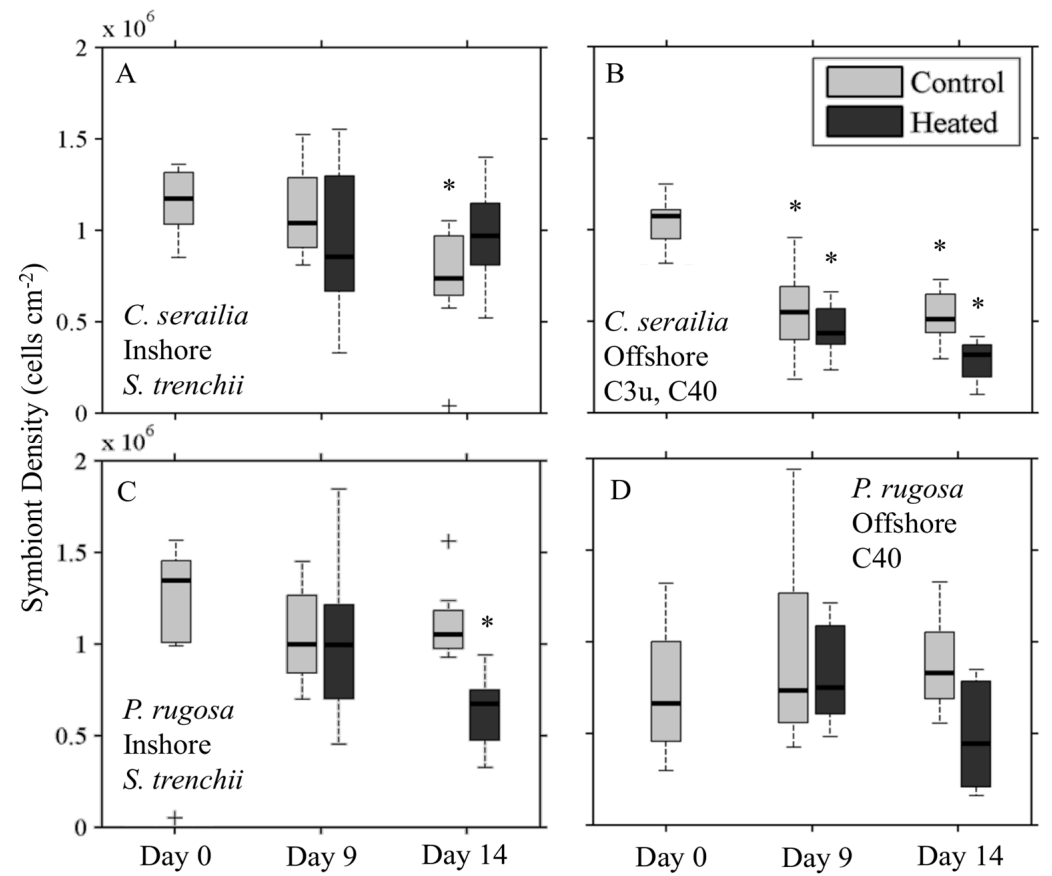

Figure 7. Symbiont cell density for coral colonies over time for control and heated treatments. Cyphastrea serailia contained Symbiodinium trenchii Inshore (A); with C3u and C40 Offshore (B); Pachyseris rugosa was associated with S. trenchii Inshore (C) and C40 and C3u Offshore (D). Asterisk denotes that the treatment is significantly different $(p<0.05)$ from the initial condition at Day 0.

For P. rugosa, Inshore symbiont (S. trenchii) densities decreased over time for both control and heated fragments (Figure 7C), though this decline was significant only for heated fragments $(p=0.02)$ on Day 14. Cell density in heated fragments was $44 \%$ percent lower than for control fragments $(p<0.001)$. Offshore, heated fragments (Figure 7D) had lower cell density (C types) on Day 14 from Day $0(p=0.18)$, and were $48 \%$ lower than control density $(p=0.06)$. For both species and sites, Day 0 densities for heated and control fragments were not collected separately.

\subsubsection{Reflectance}

\section{Cyphastrea serailia}

Colonies of $C$. serailia from Inshore and Offshore locations showed distinct responses to heating (Figure 8). On Day 0, there was no difference in mean reflectance spectra $R(\lambda)$ for all fragments for either Inshore or Offshore colonies. By Day 9, all fragment groups showed overall increased $R(\lambda)$, with Offshore colonies having a slightly higher mean reflectance at all wavelengths in response to heating. By Day 14, heated Inshore colonies had a slightly higher mean $R(\lambda)$ than the control at wavelengths above $511 \mathrm{~nm}$. Heated Offshore colonies, by contrast, showed a higher mean reflectance at all wavelengths, significant at the $\alpha=0.05$ level from $559-618 \mathrm{~nm}$.

\section{Pachyseris rugosa}

Response to heating in P. rugosa followed the same general trend as observed in C. serailia (Figure 9). Colonies from both Inshore and Offshore increased in reflectance by Day 9 for both control and heated fragments. Day 14 mean $R(\lambda)$ was not significantly different between heated and control fragments for Inshore at any wavelength. For Offshore colonies, Day 14 mean $R(\lambda)$ of heated fragments was higher at all wavelengths than for the control, but this was not significant $(\alpha=0.05)$. 


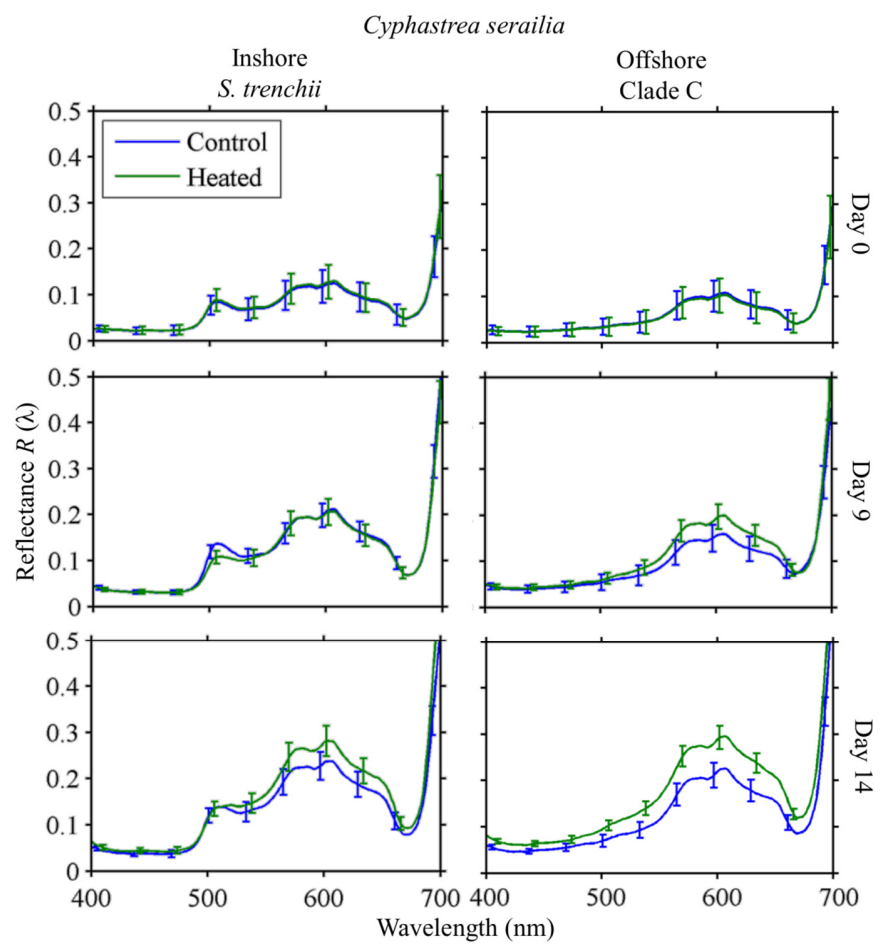

Figure 8. Cyphastrea serailia $R(\lambda)$ time series. Mean reflectance spectra at Days 0,9 , and 14 for control and heated fragments from Inshore/S. trenchii (left column) and Offshore/Clade C (right column) reefs. Error bars represent \pm 1 standard deviation, as the square root of the pooled variances for each fragment in the species/site group.
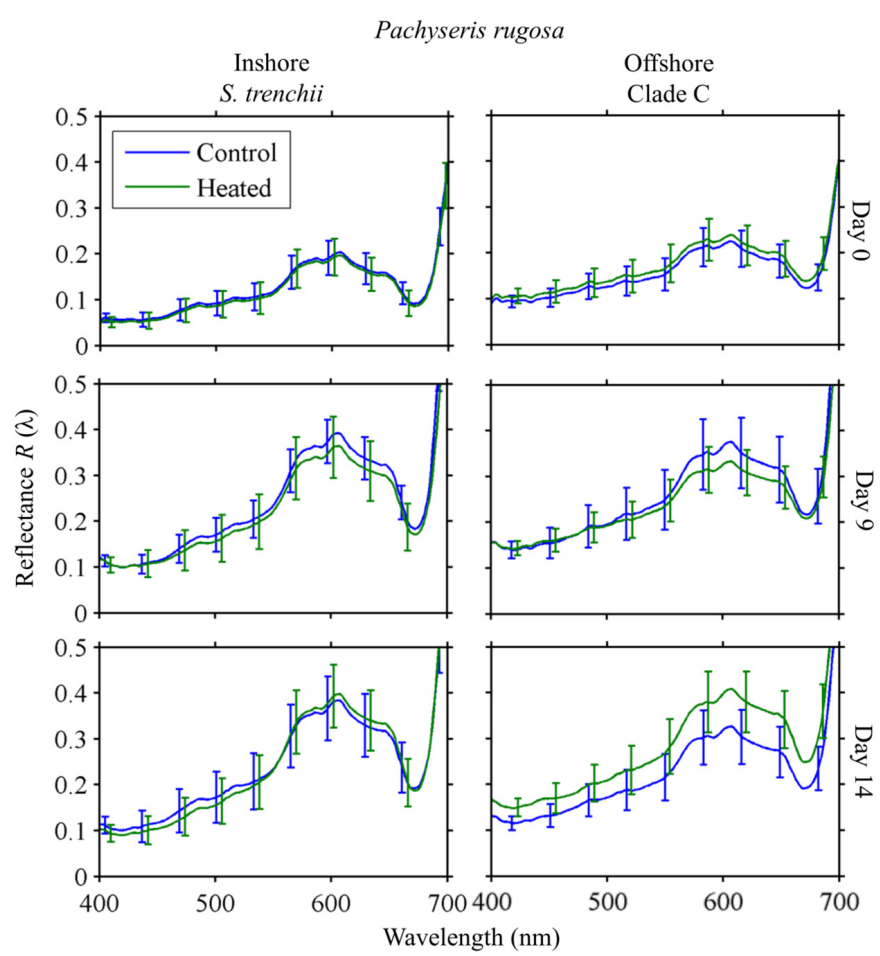

Figure 9. Pachyseris rugosa $R(\lambda)$ time series. Mean reflectance spectra at Days 0,9 , and 14 for control and heated fragments from Inshore/S. trenchii (left column) and Offshore/Clade C (right column) reefs. Error bars are \pm 1 standard deviation, as the square root of the pooled variances for each fragment in the species/site group. 


\section{Discussion}

We assessed the spectral features of two common species of reef-building coral in relationship to their symbiont species and response to thermal stress. The results are discussed in the context of spectral variability with coral species and symbiont type, areal density of symbionts, and to the effect of environmental temperature stress.

\subsection{Reflectance of Different Coral/Symbiont Systems}

The spectral shape and magnitude of reflectance of corals can be directly related to absorption, backscattering, and fluorescence features of both the host and dinoflagellate symbionts. A dip or local minima in a reflectance spectrum results from absorption by pigments, both within the photosynthetic symbionts and host tissues. Reflectance peaks can appear due to a lack of absorption compared to neighboring wavelengths or can result from pigment fluorescence. The spectral reflectance patterns of all the corals sampled were consistent with the large database of corals sampled from tropical reefs throughout the world ocean [5,59]. These corals followed the basic "triple-peaked pattern" [30] or "brown coral mode" [30] with generally low reflectance in the blue and green wavelengths $(400-450 \mathrm{~nm})$ rising in the red with local peaks around 575, 600, and $650 \mathrm{~nm}$. The triple peaked patterns were conserved regardless of symbiont genetic identity or treatment and are the result of absorption dips in neighboring wavebands due common pigments of Symbiodinium. In particular, Torres-Pérez et al. [12,60] found that common pigments in two species of Caribbean corals included chlorophyll $a$ with peaks at 427, 665, and $685 \mathrm{~nm}$, chlorophyll $c_{2}$ at $634 \mathrm{~nm}$, and diadino/diatoxanthin at $442 \mathrm{~nm}$. Peridinin, a diagnostic pigment for many dinoflagellates [12] has an absorption maximum at $475 \mathrm{~nm}$ that creates an upward slope in reflectance between 500 and $550 \mathrm{~nm}$ [24], which is evident in our measurements though partially masked in Inshore C. serailia (Figure 4) by a large fluorescence feature. The concentrations and identities of symbiont pigments in this system will be the subject of forthcoming research.

The primary spectral difference observed occurred in C. serailia colonies from our Inshore site at Nikko Bay with the symbiont S. trenchii as a distinct broad reflectance peak from 498 to $520 \mathrm{~nm}$. This feature is due largely to Green Fluorescent Proteins (GFPs) and is noted in naturally occurring reflectance measurements from other studies $[24,61,62]$. While present in all C. serailia Inshore colonies and absent from Offshore, a small feature in this region was observed in only a single colony of $P$. rugosa from both locations. However, it is possible that the GFP is a host derived photoprotection mechanism, plays an important part in thermal tolerance, and may indicate host acclimatization to the Nikko Bay environment $[63,64]$. The presence of GFPs will hinder discrimination of coral or symbiont taxa in situ due to a lack of predictability for the strength of the GFP signal and ecological parameters [59,65].

High backscattering from the underlying coral skeleton, combined with a sharp decrease in absorption by symbiont and host pigments in the far red, results in the rising reflectance at $700 \mathrm{~nm}$ also referred to as the red edge of reflectance common to vegetation [38]. Torres-Pérez et al. [12] were able to discern variability in the magnitude of near infrared reflectance related to different species of coral. Our analysis however was not able to reliably estimate the reflectance beyond $700 \mathrm{~nm}$ because of the experimental setup where the near infrared was highly absorbed due to water molecules. However, differences in near infrared are more challenging to observe in remote sensing imagery due to water absorption and may not be useful for discrimination of coral species.

\subsection{Spectral Variability with Symbiont Concentration}

Spectral reflectance was related to the symbiont concentration and the initiation of bleaching observed in offshore colonies. We investigated whether reflectance properties could be used to estimate the concentration of symbiont within coral samples. For the initial, newly collected coral samples, there was an inverse relationship between integrated reflectance and the symbiont concentration, as the photosynthetic symbionts absorb light and lower the overall reflectance of the coral. In addition 
to symbiont areal density, the concentration of pigmentation per dinoflagellate cell will have a significant impact on $\Sigma R$. The relatively low correlation between $\Sigma R$ and symbiont density in Inshore (S. trenchii) P. rugosa may be the result of significantly different photoacclimation and pigment status of the symbiont cells. Previous research found a strong inverse relation with high predictability $\left(R^{2} \geqslant 0.80\right)$ for $\Sigma R$ and total tissue pigment concentration [12,60]. Integrated reflectance shows potential as a remote sensing tool for rough estimation of symbiont cell densities, however preceding parameterizations will be required for symbiont and coral species, as illustrated here by the higher overall reflectance of $P$. rugosa compared to $C$. serailia and corresponding distinct relationships between $\Sigma R$ and symbiont density.

\subsection{Spectral Response to Heating}

Following the 1998 thermal bleaching event in Palau, Golbuu et al. [50] found that coral communities in protected bays and deep slopes were substantially less effected and recovered much more quickly than those on either shallow exposed fringe or patch reefs in Palau. This same trend was also observed after a thermal stress event in 2010 [51]. Increased heat and high irradiance can act synergistically to induce coral bleaching [2,66-70]. Both studies attributed the relative resilience of the bay communities to thermal resistance in the animal and symbionts, and reduced irradiance due to high light attenuation in bay water compared to the clear oceanic waters found at fringe and patch reef sites. Bleaching in corals results in the flattening of reflectance features and an overall increase in the magnitude of $R(\lambda)$ [24,25] as photosynthetic dinoflagellates are expelled and the bright, broadly reflective calcium carbonate skeleton influences reflectance.

Previous studies in Palau showed relative resistance to bleaching from elevated temperatures for inshore "bay" reefs [50,51]. Therefore, we expected coral fragments of both of C. serailia and $P$. rugosa from the Offshore site to show a larger increase in reflectance resulting from greater decrease in symbiont densities after heating relative to fragments from Inshore. We found that colonies of both $C$. serailia and P. rugosa from Inshore showed a negligible change in spectral reflectance with heating, while those colonies from the Offshore patch reef were more reflective than control fragments, where over the duration of the experiment they began to noticeably pale. Symbiont cell density in $C$. serailia conformed to the observed reflectance patterns, in that lower densities coincided with increased magnitude of $R(\lambda)$. Offshore colonies had significantly lower densities following heating, while Inshore colonies containing the thermally resistant $S$. trenchii did not significantly expel symbionts in response to elevated temperatures. By contrast, $P$. rugosa colonies from both Inshore and Offshore reefs showed a significant decline in endosymbiont density. Interestingly, the reflectance of heated Inshore $P$. rugosa with $S$. trenchii was not distinguishable from control fragments, despite having significantly lower cell densities. The degree to which the change in reflectance observed here is the product of symbiont expulsion or photoacclimation and pigment modification by the symbionts themselves is unknown, and will be the subject of future work.

Work on Palauan and Caribbean reefs indicate that corals with $S$. trenchii have greater thermal tolerance to increased seawater temperatures [13,14]. In the Caribbean, there is some evidence that the symbiosis is sub-optimal for some coral species as these colonies showed a lower level of calcification [16], though this may not be the case in Palau. The present study seems to indicate a lower level of thermal bleaching (as increased reflectance or loss of symbionts) in colonies with S. trenchii, compared to $\mathrm{C} 3 \mathrm{u}$ or $\mathrm{C} 40$ symbionts. An examination of calcification rates and photosynthesis in the coral-symbiont pairings studied here is forthcoming.

\section{Conclusions and Outlook for Remote Sensing}

We evaluated the in vivo spectral reflectance from two Palauan species of coral (host cnidarian) with different species of dinoflagellate (symbionts) exhibiting different thermal tolerances. The use of an imager rather than a point spectrometer allowed us to measure the range and variability in spectral reflectance across an entire coral sample. Reflectance across all treatments showed similar features, 
characteristic of brown mode reflectance [59]. A large fluorescence feature was observed in one cnidarian/dinoflagellate combination, but this could not be linked to symbiont or coral species. Under heating conditions, the magnitude of spectral reflectance increased for colonies of both coral species associated with Clade $C$ symbionts, but not those with $S$. trenchii. Symbiont concentration decreased to some degree with heating for both coral species with Clade C, while S. trenchii concentrations remained constant in one coral species and decreased with heating for the second.

The inability to find a spectral signature unique to the thermally tolerant generalist $S$. trenchii relative to the other Symbiodinium types encountered here suggests that it will be challenging to use reflectance spectroscopy to distinguish different symbionts. The similarity of the reflectance spectra from distinct host species and symbionts further supports past remote sensing studies employing inversion of a representative endmember (where an optical model is applied to field reflectance data) to identify coral and benthic constituents $[1-4,71,72]$. The relationship between integrated reflectance and symbiont concentration may prove useful to assess or monitor reef condition and the potential for bleaching. Such algorithms may be implemented using hyperspectral sensors from airborne platforms like the Portable Remote Imaging Spectrometer (PRISM) [1,38], proposed future satellite sensors, and through the use of underwater hyperspectral imagers [32,33,47,48]. However, the implementation of the algorithms will be complicated by the effects of the intervening water column, sea-surface, and atmosphere, as well as the spectral and spatial resolution of the sensor itself [24,35]. Future studies to assess how these results compare to other species of coral and symbiont from various regions are warranted.

Acknowledgments: This research was supported by National Science Foundation (IOS-1258058, -1258065, and -1258063), Office of Naval Research Multi-University Research Initiative grant N000140911054, National Aeronautics and Space Administration Biological Diversity and Ocean Biology funding to H.M.D. Award \# NNX15AC32G, and the NASA Earth Science Technology Instrument Incubator Program (IIP) for Snow and Water: Imaging Spectroscopy for Coasts and Snow Cover. We wish to thank the staff of the Palau International Coral Reef Center where work was conducted. We also wish to thank Allison Lewis and Eric Nuschke of Pennsylvania State University for assistance in the field and lab.

Author Contributions: T.C.L., M.E.W., D.W.K. conceived and designed the original experimental treatments, while B.J.R. and H.M.D. conceived and designed the spectral reflectance components. T.C.L., M.E.W., D.W.K., K.D.H., and B.J.R. conducted experiments. B.JR., H.M.D., T.C.L., K.D.H., and T.G.B. wrote the manuscript.

Conflicts of Interest: The authors declare no conflict of interest. The founding sponsors had no role in the design of the study; in the collection, analyses, or interpretation of data; in the writing of the manuscript, and in the decision to publish the results.

\section{Abbreviations}

The following abbreviations are used in this manuscript:

DGGE Denaturing gradient gel electrophoresis

GFP Green fluorescent protein

HSI Hyperspectral imaging

PCHIP Piecewise cubic hermite interpolating polynomial

PICRC Palau International Coral Reef Center

ROI Region of interest

\section{References}

1. Andréfouét, S.; Payri, C.; Hochberg, E.J.; Hu, C.; Atkinson, M.J.; Muller-Karger, F.E. Use of in situ and airborne reflectance for scaling-up spectral discrimination of coral reef macroalgae from species to communities. Mar. Ecol. Prog. Ser. 2004, 283, 161-177. [CrossRef]

2. Mumby, P.J.; Skirving, W.; Strong, A.E.; Hardy, J.T.; LeDrew, E.F.; Hochberg, E.J.; Stumpf, R.P.; David, L.T. Remote sensing of coral reefs and their physical environment. Mar. Pollut. Bull. 2004, 48, 219-228. [CrossRef] [PubMed] 
3. Goodman, J.; Ustin, S.L. Classification of benthic composition in a coral reef environment using spectral unmixing. J. Appl. Remote Sens. 2007, 1. [CrossRef]

4. Scopélitis, J.; Andréfouët, S.; Phinn, S.; Chabanet, P.; Naim, O.; Tourrand, C.; Done, T. Changes of coral communities over 35 years: Integrating in situ and remote-sensing data on Saint-Leu Reef (la Réunion, Indian Ocean). Estuar. Coast. Shelf Sci. 2009, 84, 342-352. [CrossRef]

5. Hochberg, E. Spectral reflectance of coral reef bottom-types worldwide and implications for coral reef remote sensing. Remote Sens. Environ. 2003, 85, 159-173. [CrossRef]

6. Freudenthal, H.D. Symbiodinium gen. nov. and Symbiodinium microadriaticum sp. nov., a Zooxanthella: Taxonomy, Life Cycle, and Morphology. J. Protozool. 1962, 9, 45-52. [CrossRef]

7. LaJeunesse, T. Diversity and community structure of symbiotic dinoflagellates from Caribbean coral reefs. Mar. Biol. 2002, 141, 387-400.

8. LaJeunesse, T.C.; Pettay, D.T.; Sampayo, E.M.; Phongsuwan, N.; Brown, B.; Obura, D.O.; Hoegh-Guldberg, O.; Fitt, W.K. Long-standing environmental conditions, geographic isolation and host-symbiont specificity influence the relative ecological dominance and genetic diversification of coral endosymbionts in the genus Symbiodinium. J. Biogeogr. 2010, 37, 785-800. [CrossRef]

9. Thornhill, D.J.; Lewis, A.M.; Wham, D.C.; LaJeunesse, T.C. Host-specialist lineages dominate the adaptive radidation of reef coral endosymbionts. Evolution 2014, 68, 352-367. [CrossRef] [PubMed]

10. LaJeunesse, T.C.; Loh, W.K.; Van Woesik, R.; Hoegh-Guldberg, O.; Schmidt, G.W.; Fitt, W.K. Low symbiont diversity in southern Great Barrier Reef corals, relative to those of the Caribbean. Limnol. Oceanogr. 2003, 48, 2046-2054. [CrossRef]

11. Tonk, L.; Sampayo, E.M.; LaJeunesse, T.C.; Schrameyer, V.; Hoegh-Guldberg, O. Symbiodinium (Dinophyceae) diversity in reef-invertebrates along an offshore to inshore reef gradient near Lizard Island, Great Barrier Reef. J. Phycol. 2014, 50, 552-563. [CrossRef]

12. Torres-Pérez, J.L.; Guild, L.S.; Armstrong, R.A. Hyperspectral distinction of two Caribbean shallow-water corals based on their pigments and corresponding reflectance. Remote Sens. 2012, 4, 3813-3832. [CrossRef]

13. Kemp, D.W.; Hernandez-Pech, X.; Iglesias-Prieto, R.; Fitt, W.K.; Schmidt, G.W. Community dynamics and physiology of Symbiodinium spp. before, during, and after a coral bleaching event. Limnol. Oceanogr. 2014, 59, 788-797. [CrossRef]

14. LaJeunesse, T.C.; Smith, R.T.; Finney, J.; Oxenford, H. Outbreak and persistence of opportunistic symbiotic dinoflagellates during the 2005 Caribbean mass coral "bleaching"event. Proc. R. Soc. B Biol. Sci. 2009, 276, 4139-4148. [CrossRef] [PubMed]

15. LaJeunesse, T.C.; Wham, D.C.; Pettay, D.T.; Parkinson, J.E.; Keshavmurthy, S.; Chen, C.A. Ecologically differentiated stress-tolerant endosymbionts in the dinoflagellate genus Symbiodinium (Dinophyceae) Clade D are different species. Phycologia 2014, 53, 305-319. [CrossRef]

16. Pettay, D.T.; Wham, D.C.; Smith, R.T.; Iglesias-Prieto, R.; LaJeunesse, T.C. Microbial invasion of the Caribbean by an Indo-Pacific coral zooxanthella. Proc. Natl. Acad. Sci. USA 2015, 112, 7513-7518. [CrossRef] [PubMed]

17. Ragni, M.; Ruth, A.L.; Hennige, S.J.; Suggett, D.J.; Warner, M.E.; Geider, R.J. PSII photoinhibition and photorepair in Symbiodinium (Pyrrhophyta) differs between thermally tolerant and sensitive phylotypes. Mar. Ecol. Prog. Ser. 2010, 406, 57-70. [CrossRef]

18. Robison, J.D.; Warner, M.E. Differential impacts of photoacclimation and thermal stress on the photobiology of four different phylotypes of Symbiodinium (Pyrrhophyta). J. Phycol. 2006, 42, 568-579. [CrossRef]

19. Steinke, M.; Brading, P.; Kerrison, P.; Warner, M.E.; Suggett, D.J. Concentrations of dimethylsulfoniopropionate and dimethyl sulfide are strain-specific in symbiotic dinoflagellates (Symbiodinium sp., Dinophyceae). J. Phycol. 2011, 47, 775-783. [CrossRef]

20. Berkelmans, R.; van Oppen, M.J. The role of zooxanthellae in the thermal tolerance of corals: A "nugget of hope" for coral reefs in an era of climate change. Proc. R. Soc. B Biol. Sci. 2006, 273, 2305-2312. [CrossRef] [PubMed]

21. Grottoli, A.G.; Warner, M.E.; Levas, S.J.; Aschaffenburg, M.D.; Schoepf, V.; McGinley, M.; Baumann, J.; Matsui, Y. The cumulative impact of annual coral bleaching can turn some coral species winners into losers. Glob. Chang. Biol. 2014, 20, 3823-3833. [CrossRef] [PubMed]

22. Silverstein, R.N.; Cunning, R.; Baker, A.C. Change in algal symbiont communities after bleaching, not prior heat exposure, increases heat tolerance of reef corals. Glob. Change Biol. 2015, 21, 236-249. [CrossRef] [PubMed] 
23. Enríquez, S.; Méndez, E.R.; Prieto, R.I. Multiple scattering on coral skeletons enhances light absorption by symbiotic algae. Limnol. Oceanogr. 2005, 50, 1025-1032. [CrossRef]

24. Hedley, J.D.; Mumby, P.J. Biological and remote sensing perspectives of pigmentation in coral reef organisms. Adv. Mar. Biol. 2002, 43, 277-317. [PubMed]

25. Holden, H.; LeDrew, E. Spectral discrimination of healthy and non-healthy corals based on cluster analysis, principal components analysis, and derivative spectroscopy. Remote Sens. Environ. 1998, 65, 217-224. [CrossRef]

26. Joyce, K.E.; Phinn, S.R. Hyperspectral analysis of chlorophyll content and photosynthetic capacity of coral reef substrates. Limnol. Oceanogr. 2003, 48, 489-496. [CrossRef]

27. Ralph, P.J.; Larkum, A.W.D.; Kühl, M. Photobiology of endolithic microorganisms in living coral skeletons: 1. Pigmentation, spectral reflectance and variable chlorophyll fluorescence analysis of endoliths in the massive corals Cyphastrea serailia, Porites lutea and Goniastrea australensis. Mar. Biol. 2007, 152, 395-404. [CrossRef]

28. Rodríguez-Román, A.; Hernández-Pech, X.; E Thome, P.; Enríquez, S.; Iglesias-Prieto, R. Photosynthesis and light utilization in the Caribbean coral Montastraea faveolata recovering from a bleaching event. Limnol. Oceanogr. 2006, 51, 2702-2710. [CrossRef]

29. Clark, C.D.; Mumby, P.J.; Chisholm, J.R.M.; Jaubert, J.; Andréfouét, S. Spectral discrimination of coral mortality states following a severe bleaching event. Int. J. Remote Sens. 2000, 21, 2321-2327. [CrossRef]

30. Hochberg, E.J.; Atkinson, M.J. Spectral discrimination of coral reef benthic communities. Coral Reefs 2000, 19, 164-171. [CrossRef]

31. Myers, M.R.; Hardy, J.T.; Mazel, C.H.; Dustan, P. Optical spectra and pigmentation of Caribbean reef corals and macroalgae. Coral Reefs 1999, 18, 179-186. [CrossRef]

32. Caras, T.; Karnieli, A. Ground-level spectroscopy analyses and classification of coral reefs using a hyperspectral camera. Coral Reefs 2013, 32, 825-834. [CrossRef]

33. Caras, T.; Karnieli, A. Ground-level classification of a coral reef using a hyperspectral camera. Remote Sens. 2015, 7, 7521-7544. [CrossRef]

34. Leiper, I.; Phinn, S.; Dekker, A.G. Spectral reflectance of coral reef benthos and substrate assemblages on Heron Reef, Australia. Int. J. Remote Sens. 2012, 33, 3946-3965. [CrossRef]

35. Lucas, M.; Goodman, J. Linking coral reef remote sensing and field ecology: It's a matter of scale. J. Mar. Sci. Eng. 2014, 3, 1-20. [CrossRef]

36. Anderson, D.A.; Armstrong, R.A.; Weil, E. Hyperspectral sensing of disease stress in the Caribbean reef-building coral, Orbicella faveolata-Perspectives for the field of coral disease monitoring. PLoS ONE 2013, 8, e81478. [CrossRef] [PubMed]

37. Hochberg, E.J.; Apprill, A.M.; Atkinson, M.J.; Bidigare, R.R. Bio-optical modeling of photosynthetic pigments in corals. Coral Reefs 2006, 25, 99-109. [CrossRef]

38. Dierssen, H.M.; Chlus, A.; Russell, B. Hyperspectral discrimination of floating mats of seagrass wrack and the macroalgae sargassum in coastal waters of Greater Florida Bay using airborne remote sensing. Remote Sens. Environ. 2015, 167, 247-258. [CrossRef]

39. Mahlein, A.K.; Steiner, U.; Hillnhütter, C.; Dehne, H.W.; Oerke, E.C. Hyperspectral imaging for small-scale analysis of symptoms caused by different sugar beet diseases. Plant Methods 2012, 8. [CrossRef] [PubMed]

40. Nansen, C.; Ribeiro, L.P.; Dadour, I.; Roberts, J.D. Detection of temporal changes in insect body reflectance in response to killing agents. PLOS ONE 2015, 10, e0124866. [CrossRef] [PubMed]

41. Rascher, U.; Nichol, C.J.; Small, C.; Hendricks, L. Monitoring spatio-temporal dynamics of photosynthesis with a portable hyperspectral imaging system. Photogramm. Eng. Remote Sens. 2007, 73, 45-56. [CrossRef]

42. Römer, C.; Wahabzada, M.; Ballvora, A.; Pinto, F.; Rossini, M.; Panigada, C.; Behmann, J.; Léon, J.; Thurau, C.; Bauckhage, C.; et al. Early drought stress detection in cereals: Simplex volume maximisation for hyperspectral image analysis. Funct. Plant Biol. 2012, 39, 878-890. [CrossRef]

43. Russell, B.J.; Dierssen, H.M. Use of hyperspectral imagery to assess cryptic color matching in sargassum associated crabs. PLoS ONE 2015, 10, e0136260. [CrossRef] [PubMed]

44. Behrendt, L.; Larkum, A.W.; Norman, A.; Qvortrup, K.; Chen, M.; Ralph, P.; Sørensen, S.J.; Trampe, E.; Kühl, M. Endolithic chlorophyll d-containing phototrophs. ISME J. 2011, 5, 1072-1076. [CrossRef] [PubMed]

45. Kühl, M.; Polerecky, L. Functional and structural imaging of phototrophic microbial communities and symbioses. Aquat. Microb. Ecol. 2008, 53, 99-118. [CrossRef] 
46. Mehrubeoglu, M.; Smith, D.K.; Smith, S.W.; Strychar, K.B.; McLauchlan, L. Investigating coral hyperspectral properties across coral species and coral state using hyperspectral imaging. Proc. SPIE 2013. [CrossRef]

47. Johnsen, G.; Volent, Z.; Dierssen, H.; Pettersen, R.; Ardelan, M.V.; Søreide, F.; Fearns, P.; Ludvigsen, M.; Moline, M. Underwater hyperspectral imagery to create biogeochemical maps of seafloor properties. In Subsea Optics and Imaging; Elsevier: Amsterdam, The Netherlands, 2013; pp. 508-540.

48. Dierssen, H.M. Overview of hyperspectral remote sensing for mapping marine benthic habitats from airborne and underwater sensors. Proc. SPIE 2013. [CrossRef]

49. Chennu, A.; Färber, P.; Volkenborn, N.; Al-Najjar, M.A.A.; Janssen, F.; de Beer, D.; Polerecky, L. Hyperspectral imaging of the microscale distribution and dynamics of microphytobenthos in intertidal sediments: Hyperspectral imaging of MPB biofilms. Limnol. Oceanogr. Methods 2013, 11, 511-528. [CrossRef]

50. Golbuu, Y.; Victor, S.; Penland, L.; Idip, D.; Emaurois, C.; Okaji, K.; Yukihira, H.; Iwase, A.; van Woesik, R. Palau's coral reefs show differential habitat recovery following the 1998-bleaching event. Coral Reefs 2007, 26, 319-332. [CrossRef]

51. Van Woesik, R.; Houk, P.; Isechal, A.L.; Idechong, J.W.; Victor, S.; Golbuu, Y. Climate-change refugia in the sheltered bays of Palau: Analogs of future reefs. Ecol. Evol. 2012, 2, 2474-2484. [CrossRef] [PubMed]

52. Golbuu, Y.; Bauman, A.; Kuartei, J.; Victor, S. The state of coral reef ecosystems of Palau. In The State of Coral Reef Ecosystems of the United States and Pacific Freely Associated States; National Oceanic and Atmospheric Administration, National Ocean Service, National Centers for Coastal Ocean Science: Silver Spring, MD, USA, 2005; pp. 488-507.

53. Barkley, H.C.; Cohen, A.L.; Golbuu, Y.; Starczak, V.R.; DeCarlo, T.M.; Shamberger, K.E.F. Changes in coral reef communities across a natural gradient in seawater $\mathrm{pH}$. Sci. Adv. 2015. [CrossRef] [PubMed]

54. Szmant, A.M.; Gassman, N.J. The effects of prolonged "bleaching" on the tissue biomass and reproduction of the reef coral Montastrea annularis. Coral Reefs 1990, 8, 217-224. [CrossRef]

55. Fitt, W.K.; McFarland, F.K.; Warner, M.E.; Chilcoat, G.C. Seasonal patterns of tissue biomass and densities of symbiotic dinoflagellates in reef corals and relation to coral bleaching. Limnol. Oceanogr. 2000, 45, 677-685. [CrossRef]

56. Suggett, D.J.; Prášil, O.; Borowitzka, M.A. Chlorophyll a Fluorescence in Aquatic Sciences: Methods and Applications; Springer: Dordrecht, The Netherlands, 2010.

57. Marsh, J.A. Primary productivity of reef-building calcareous red algae. Ecology 1970, 51, 255-263. [CrossRef]

58. Zhang, H.; Voss, K.J. Bi-directional reflectance of dry and submerged Labsphere Spectralon plaque. Appl. Opt. 2006, 45, 7924-7927.

59. Hochberg, E.J.; Atkinson, M.J.; Apprill, A.; Andréfouét, S. Spectral reflectance of coral. Coral Reefs 2004, 23, 84-95. [CrossRef]

60. Torres-Pérez, J.L.; Guild, L.S.; Armstrong, R.A.; Corredor, J.; Zuluaga-Montero, A.; Polanco, R. Relative pigment composition and remote sensing reflectance of Caribbean shallow-water corals. PLoS ONE 2015, 10, e0143709. [CrossRef] [PubMed]

61. Mazel, C.H. Coral fluorescence characteristics: Excitation/emmission spectra, fluorescence efficiences, and contribution to apparent reflectance. Proc. SPIE 1997. [CrossRef]

62. Mazel, C.H.; Fuchs, E. Contribution of fluorescence to the spectral signature and perceived color of corals. Limnol. Oceanogr. 2003, 48, 390-401. [CrossRef]

63. Salih, A.; Larkum, A.W.; Cox, G.; Kühl, M.; Hoegh-Guldberg, O. Fluorescent pigments in corals are photoprotective. Nature 2000, 408, 850-853. [CrossRef] [PubMed]

64. Bou-Abdallah, F.; Chasteen, N.D.; Lesser, M.P. Quenching of superoxide radicals by green fluorescent protein. Biochim. Biophys. Acta 2006, 1760, 1690-1695. [CrossRef] [PubMed]

65. Mazel, C.H.; Strand, M.P.; Lesser, M.P.; Crosby, M.P.; Coles, B.; Nevis, A.J. High-resolution determination of coral reef bottom cover from multispectral fluorescence laser line scan imagery. Limnol. Oceanogr. 2003, 48, 522-534. [CrossRef]

66. Iglesias-Prieto, R.; Trench, R.K. Acclimation and adaptation to irradiance in symbiotic dinoflagellates. I. Responses of the photosynthetic unit to changes in photon flux density. Mar. Ecol. Prog. Ser. 1994, 113, 163-175. [CrossRef]

67. Iglesias-Prieto, R.; Beltran, V.H.; LaJeunesse, T.C.; Reyes-Bonilla, H.; Thome, P.E. Different algal symbionts explain the vertical distribution of dominant reef corals in the eastern Pacific. Proc. R. Soc. Lond. B Biol. Sci. 2004, 271, 1757-1763. [CrossRef] [PubMed] 
68. Nakamura, T.; van Woesik, R.; Yamasaki, H. Photoinhibition of photosynthesis is reduced by water flow in the reef-building coral Acropora digitifera. Mar. Ecol. Prog. Ser. 2005, 301, 109-118. [CrossRef]

69. Takahashi, S.; Nakamura, T.; Sakamizu, M.; van Woesik, R.; Yamasaki, H. Repair machinery of symbiotic photosynthesis as the primary target of heat stress for reef-building corals. Plant Cell Physiol. 2004, 45, 251-255. [CrossRef] [PubMed]

70. Warner, M.E.; Fitt, W.K.; Schmidt, G.W. The effects of elevated temperature on the photosynthetic efficiency of zooxanthellae in hospite from four different species of reef coral: A novel approach. Plant Cell Environ. 1996, 19, 291-299. [CrossRef]

71. Reichstetter, M.; Fearns, P.; Weeks, S.; McKinna, L.; Roelfsema, C.; Furnas, M. Bottom reflectance in ocean color satellite remote sensing for coral reef environments. Remote Sens. 2015, 7, 16756-16777. [CrossRef]

72. Garcia, R.; Hedley, J.; Tin, H.; Fearns, P. A method to analyze the potential of optical remote sensing for benthic habitat mapping. Remote Sens. 2015, 7, 13157-13189. [CrossRef]

(C) 2016 by the authors; licensee MDPI, Basel, Switzerland. This article is an open access article distributed under the terms and conditions of the Creative Commons by Attribution (CC-BY) license (http://creativecommons.org/licenses/by/4.0/). 